\title{
INTER-MUNICIPAL COOPERATION IN THE DEVELOPMENT OF INDUSTRIAL PARKS AND TAX REDISTRIBUTION: THE ROAD TO HELL IS PAVED WITH GOOD INTENTIONS
}

\author{
ERAN RAZIN \\ Department of Geography, The Hebrew University, Jerusalem, Israel \\ Manuscript received: November 19, 2015 \\ Revised version: March 18, 2016
}

\begin{abstract}
RAZIN E., 2016. Inter-municipal cooperation in the development of industrial parks and tax redistribution: The road to hell is paved with good intentions. Quaestiones Geographicae 35(2), Bogucki Wydawnictwo Naukowe, Poznań, pp. 83-90, 1 fig.

ABSTRACT: Inter-municipal cooperation mechanisms have been promoted as flexible tools, reflecting the transition from government to governance in a new network economy and eliminating the need to engage in redrawing clear-cut boundaries in the context of soft spaces with fuzzy boundaries. An evaluation of inter-municipal cooperation in the development of industrial parks and tax revenue redistribution in Israel, from the first 1992 initiative to imposed redistribution in 2014/15, reveals how an initiative 'from below' has been adopted and encouraged 'from above', finally used by the central state as a tool of control, to serve its own objectives. It highlights the inherent temptation for topdown imposition, embedded in bottom-up cooperation mechanisms, calling for light-touch regulatory legislation and opting for gently imposed solutions where needed.
\end{abstract}

KEY WORDS: inter-municipal cooperation, government, governance, industrial parks, tax redistribution, Israel

Eran Razin, Department of Geography, The Hebrew University, Jerusalem 91905, Israel; msrazin@mail.huji.ac.il

\section{Introduction: the growing emphasis on inter-municipal cooperation}

A transition from government to governance - from political-administrative hierarchical structures to horizontal networks - has been evident and subjected to much research in the last two decades (Savitch, Vogel 2000; Héritier, Lehmkuhl 2008; Smismans 2008). This transformation has been interpreted as a response to pressures of globalisation, being part of the emerging new economy of flexible networks. Inter-sectoral and intra-sectoral partnerships have proliferated in local governance. The former include, for example, public-private partnerships of various types (Razin, Hazan 2013), and the latter include inter-municipal partnerships that aim at efficient service delivery by capturing economies of scale, and at improved competitiveness in the global economy by joining forces rather than excessively engaging at zero-sum intra-regional competition (Thurmaier, Wood 2004; Hulst, van Monfort 2007). Such partnerships that reduce the significance of formal hierarchies and clear-cut boundaries are in line with notions of soft spaces with fuzzy boundaries (Allmendinger, Haughton 2009; Haughton et al. 2013), emphasising competition between different city-regions that lack clear spatial delineation. 
However, the ability of partnerships and cooperation networks to serve as a substitute for government hierarchies and clear boundaries can be challenged. Inter-municipal partnerships are prone to instability, depending, for example, on political leadership, i.e. the character of cooperating mayors (Spicer 2014). Inter-municipal organisations are also prone to democratic deficit and accountability problems, being more detached than core institutions of the local authority from the scrutiny of voters and elected politicians (Ruano de la Fuente, Schaap 2007; Schaap, Daemen 2012). In Israel, for example, fire-fighting municipal unions (each being a joint organisation of several local authorities) were a remarkable example for failed partnerships that lacked effective regulation by either central or local government. They were dismantled following poor performance in the 2010 Mount Carmel forest fire. Finally, inter-municipal cooperation can be practically imposed on local authorities, as was the case with Israel's fire-fighting municipal unions, and is prone to being 'nationalised' by upper-level governments.

Inter-municipal cooperation can be voluntary, compulsory or 'gently imposed'. Voluntary cooperation is most likely to evolve when joining forces against a common threat. It can also be motivated by a desire for greater effectiveness an improved quality of services - that compels small localities to cooperate or to buy services from adjacent ones. Cooperation might be 'gently imposed' by upper level governments (Tennant, Zirnhelt 1973), frequently aiming to increase efficiency by achieving economies of scale while avoiding amalgamation; aiming to jointly promote regional/local economic development/coordinated development, or to resolve territorial conflicts. Such gentle imposition could include incentives and penalties to promote objectives that are beneficial for both the local and the central state, to be employed when voluntary cooperation faces political barriers at the local level. Compulsory cooperation is likely to be needed to promote aspects of sustainable development, and particularly when the primary objective concerns redistribution and social justice.

The complex experience of French intercommunalité - a powerful form of cooperation between communes, promoted since 1999 - reveals the challenges of modes of inter-municipal cooperation (Wollmann 2010). Intercommunalités are associated with additional costs rather than with reducing the cost of service provision, largely due to a duplication of tasks (Kerrouche 2008; Nemery 2010; Desage, Guéranger 2013). At least in their early years, they also increased rather than reduced disparities, because affluent communes tended to align with other wealthy communes, forming 'clubs de riches'. The abolition of the professional tax undermined their financial base, creating an increased burden on the central state and leading to the possible abolition of the départements. Hence, being initially a major component of encouraging local initiative, the intercommunalité evolved to become compulsory collaboration, practically forming a new level of local government. Elections of intercommunalité councils, held in 2014, and the establishment of 11 métropoles (metropolitan intercommunalités) in 2015 , could practically mean the re-delineation of French municipal boundaries, leading to the creation of a new level of government, probably to the weakening or dismantling of one of the other tiers rather than strengthening inter-municipal cooperation.

In this paper I discuss the case of inter-municipal cooperation in the development of industrial parks in Israel, from the first local initiative in 1992 to the imposed tax revenue redistribution in 2014/15. The Israeli case reveals how an initiative 'from below' has been adopted 'from above', serving the central state as a tool of control, mainly to promote distributive justice. It suggests an inherent temptation for top-down imposition embedded in bottom-up cooperation mechanisms, at least in the centralised Israeli political context. The study consisted of an in-depth analysis of inter-municipal cooperation agreements, reports of relevant municipal boundary and revenue redistribution commissions, additional documents, and participant observation of the author, who has served as member and chair of such commissions continuously since 1987 . This paper does not present a detailed account of various examples, but rather outlines major transformations in the character of these initiatives since their inception in the early 1990s. 


\section{The evolution of joint municipal corporations for the development of industrial parks in Israel}

Non-residential property taxes deriving from business/commercial/industrial land uses, infrastructural facilities and state-owned assets (army bases, etc.) have a major contribution to the fiscal strength of local authorities in Israel. Revenues from non-residential property taxes are far higher than the cost of servicing these properties, while the opposite is true for residential land uses (Razin, Hazan 2006). The development of industrial/business parks through local government initiative could be motivated also by the objectives of job creation and local economic development, significant particularly in Israel's weaker peripheral regions that aspire to improve the well-being of their residents, thus reducing welfare costs and residential property tax exemptions.

Joint administration of industrial parks, including the redistribution of local tax revenues collected there, has become one of the more substantial mechanisms of inter-municipal cooperation in Israel, demonstrating both their potential and limitations. It is a (typical?) example of a voluntary initiative 'from below' that has been 'nationalised' by the central state for its own purposes. What started in 1992 as local initiatives of mayors was gradually adopted as a tool imposed, not necessarily in an effective manner, by the central state to serve its own objectives, mainly distributive justice, reducing central-state expenditures and preserving open space.

\section{2-1997. The beginnings: a local initiative}

The first joint industrial park - the ZHR Galilee Industrial Park - was established in 1992 by three small municipalities in Israel's north-eastern periphery: Zefat, Hazor HaGelilit and Rosh Pinna (Fig. 1). It was mainly a local initiative of the mayor of Zefat, who proposed cooperation in order to promote regional development by concentrating efforts on one best-located industrial park rather than engaging in inter-local competition. A joint urban corporation was established to develop and manage the industrial park, including a property tax base sharing mechanism. The Ministry of the
Interior supported the initiative and was particularly instrumental in mitigating bitter disputes that emerged after new mayors were elected in Zefat and Rosh Pinna in 1993.

Dozens of such inter-municipal agreements followed the ZHR precedent, mainly as a solution to municipal boundary conflicts over land for the development of business parks (Razin 1998). The most substantial was the 1995 Y.S.Gat industrial park agreement between the city of Qiryat Gat and two rural regional councils: Yoav and Shafir. The agreement included the transfer of land for the establishment of the park from the two regional councils to Qiryat Gat, in return for joint management by an urban corporation and sharing tax

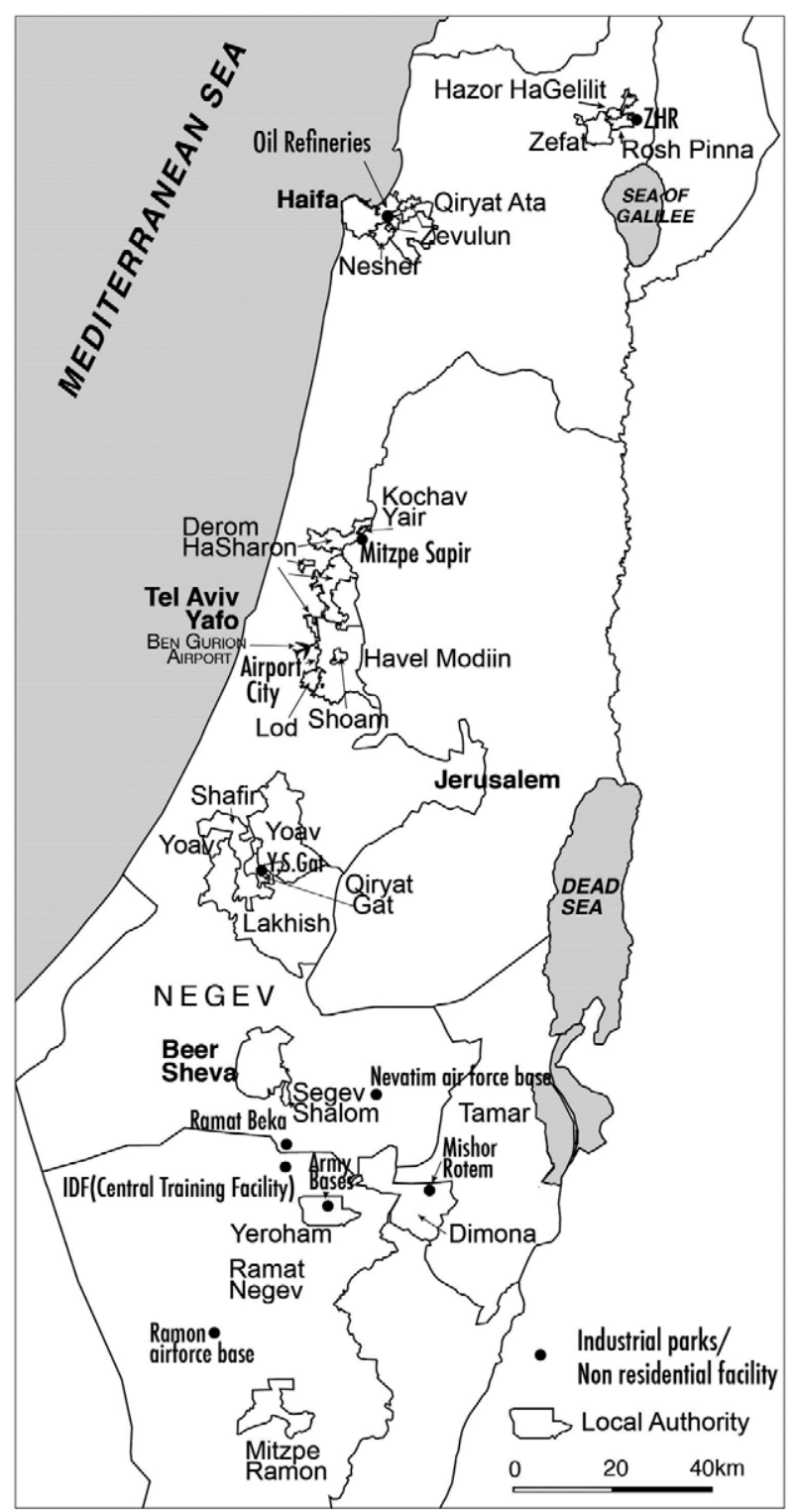

Fig. 1. Selected revenue redistribution areas and the local authorities involved (2014 boundaries). 
revenues. It enabled the establishment of Intel's FAB18 in the park in 1999 and the adjacent FAB28 in 2008. Although (or because) property tax revenues were most substantial, disagreements over tax sharing erupted soon after the establishment of the park, intensifying after a new mayor was elected in Qiryat Gat in 2003. The mayor attempted to back off from the redistribution agreement by not transferring revenues to the regional councils. The agreement was modified three times, but survived, although in an ongoing state of conflict.

\section{7-2006. Discovered and encouraged by the central state to promote its objectives}

The Ministry of the Interior, responsible for Israel's local authorities, supported inter-municipal cooperation in the establishment of industrial parks from their early beginnings, mainly by providing professional assistance and conflict mediation. However, the proliferation of the new cooperation mechanism soon attracted the attention of other central-state agencies as a possible tool that could be encouraged in order to achieve their own objectives.

Being required by the Ministry of Finance to obtain revenues from marketing land in peripheral industrial parks as a condition for further central-state funding in developing such parks, the Ministry of Industry and Trade needed a tool to market land for industrial development in Israel's periphery. Joint industrial parks could reduce the risk of over-investment in infrastructure that would not yield revenues, and the managing urban corporations of these parks could engage in marketing lots. Hence, in 1997 the Ministry started to 'gently impose' inter-municipal cooperation as a pre-condition for central-state funding of infrastructure in peripheral industrial parks. Making inter-municipal cooperation a condition for state funding of infrastructure and management of the park served as the major incentive to encourage or, in fact, impose cooperation. The Ministry of Industry and Trade supported 22 joint industrial parks in Israel's periphery in the late 1990s. However, support dwindled in the early 2000s, because of a large budget deficit caused by the diversion of funds to industrial parks affiliated with Jewish settlements on the West Bank, where marketing came to a halt when the second Intifada (Palestinian uprising) broke out in 2000.
Revenue redistribution was encouraged by the central state in the early 2000s in order to preserve scarce open space and reduce public expenditure. Israel's National Planning Administration incorporated the joint industrial parks idea in its national and regional (district) outline plans, for example the National Outline Plan no. 35 prepared in 1998/9 and approved in 2005. It aimed to reduce sprawl and conserve scarce open space by avoiding the fragmentation of economic land uses into too many small industrial parks. The severe recession in the years of the Palestinian uprising (2001-2004), coupled with neoliberal policies of the Ministry of Finance, led in 2003 to sharp cuts in the equalisation grants transferred by the Ministry of the Interior to local authorities (Heinelt et al. 2011). Consequently, weak local authorities that depended more on grants plunged into a deep financial crisis, later on restructuring and recovering far slower than the more sound municipalities. Thus, in subsequent years, the Ministry of Finance opted to mitigate the impact of those sharp cuts on growing fiscal disparities without reversing them.

The redistribution of non-residential property tax revenues was viewed as a means to improve the financial position of failing local authorities by the transfer of funds from local authorities endowed with ample non-residential property tax revenues to those lacking such a tax base. Revenue redistribution at the national scale is extremely difficult because it diverts resources from the politically powerful to the politically weakest (mainly Arab municipalities). Moreover, a proposal to nationalise $20 \%$ of the non-residential property tax, in order to redistribute funds according to a formula that favours weak local authorities, was rejected in 2004 by a commission appointed by the Ministry of the Interior (the Gadish Commission). The commission feared that such a nationalisation of non-residential property tax revenues would eventually lead to a parallel reduction in the central-state equalisation grants; hence the pool of shared tax revenues would be offset by a reduction in grants. The Gadish Commission proposed institutionalising and strengthening local agreements for joint development and administration of industrial parks, and assessing the option of redistributing revenues from 'national facilities' (mainly large mineral-extracting complexes, infrastructure and 
military facilities). Many of these facilities are owned by the central state, but pay full property taxes in most local authorities in Israel's periphery and in some of those located in its central regions, and pay partial property taxes in the rest. The rationale for redistributing this revenue is based on regarding these facilities as national ones that owe little to local initiative.

There were two attempts to impose property tax revenue redistribution indirectly through municipal boundary commissions: in the Mishor Rotem mineral-extracting industrial zone in the Negev desert, in 2004, and the Mitzpe Sapir industrial zone in suburban Tel Aviv, in 2002 (Fig. 1). These attempts to encourage redistribution, by hinting that a refusal to share revenues would lead to annexing the land in question to another local authority, failed. The inability of the central state to enforce its will, despite its legal authority to impose municipal boundary changes (Razin, Hazan 2001), was a consequence of either insufficient political determination of the Minister of the Interior, or effective political and legal battles of those opposing redistribution, who benefited from political instability at the central-state level. The central-state initiated revenue redistribution proved successful only in one case, in 2004: sharing property tax revenues of the Haifa Bay oil refineries complex by the four bordering municipalities: Haifa, Nesher, Qiryat Ata, and Zevulun. Nevertheless, those facilities previously lacked municipal jurisdiction; hence, this decision did not involve sharing the existing revenues, and the only opposition came from the facilities themselves and from adjacent local authorities not included in the sharing mechanism.

\section{6-2013. Enabling the imposition of property tax redistribution leads to a stalemate}

The transfer of property tax revenues from one local authority to another was not based on a sound legal foundation, and faced the risk that such agreements would be challenged in courts. A legal amendment in the year 2000 aimed to reduce this uncertainty, by allowing the Minister of the Interior to approve tax sharing agreements (the transfer of property tax revenues from one local authority to another) in joint industrial/ business parks (Section 9a of the Municipalities
Order). However, the amendment was not implemented until 2013, because the legal bureaucracy of the Ministry of the Interior was unenthusiastic about the prospect of the Minister becoming guarantor to local agreements, having to take responsibility in subsequent disputes, and enforcing fund transfers on local authorities that violate signed agreements.

A further amendment, empowering the Minister of the Interior, with the approval of the Minister of Finance, to impose redistribution of non-residential property tax revenues among adjacent (not necessarily bordering) local authorities, was passed in 2006 (Section 9b of the Municipalities Order). It was an initiative of the Ministry of Finance - a reaction to the inability to pass the 'big plan' of a nationwide redistribution of a portion of property taxes. However, the amendment was not implemented even once until 2014.

Rather than encouraging new agreements for the establishment of joint industrial/business parks, the legal institutionalisation of revenue redistribution seemed to have paralysed further initiatives. All functioning joint industrial parks and redistribution mechanisms were a product of agreements signed before the passage of the legal amendment. The redistribution of the non-residential property tax revenue from wealthy cities and regional councils to poorer cities and towns, in the name of distributional justice, has gained a high position on the agenda of the Ministers of the Interior since 2007. A substantial number of revenue redistribution commissions of enquiry (a prerequisite prior to making the decision) were appointed in 2008 and in subsequent years, but the Ministry of the Interior failed to sign an order for revenue redistribution even for minor and simple cases agreed upon by both sides. This failure could be attributed to legal-bureaucratic and political obstacles.

Legal and economic gatekeepers, i.e. the senior bureaucracy of the Ministries of Law and Finance, feared that the imposed redistribution would be motivated by narrow political considerations; hence, they inserted in the legal amendment a sub-section that apparently enabled the Minister to either accept or reject the recommendations of the appointed commission of inquiry, but not to modify them. Such a sub-section that went unnoticed in the legislation process had 
a crippling effect on the ability to implement the imposed redistribution.

Another legal-bureaucratic obstacle was the (unrealistic) desire of the legal bureaucracy to define universal criteria for revenue redistribution. The definition of such criteria seemed just and logical, but it was very difficult to adapt a nationwide formula to local circumstances; implementation at the local level could frequently lead to distorted outcomes. Moreover, universal criteria would channel resources from the politically powerful to the least powerful (mainly Arab local authorities), further reducing prospects for their adaptation by elected decision-makers. Indeed, attempts to define a universal formula failed and the proposed formulas served revenue redistribution commissions only as suggestive tools.

Political obstacles have even been more profound, including pressures of capitalists, particularly property owners at the business/industrial park, who fear increased property taxes, and mayors with good contacts at the central-state level, particularly in the context of Party primaries and Party centres. The case of the Airport City - a successful high-tech, business and logistics park near the Ben Gurion International Airport demonstrates such pressures. The business park was established as a private initiative in the late 1990s, within the Hevel Modiin regional council (Fig. 1). It received few services from the regional council and paid low property taxes. A Ministry of the Interior initiative to impose tax revenue redistribution with the adjacent poor city of Lod, along with an increase in the low property tax rates in the park, apparently encountered substantial political barriers. They included political contacts of the park's private owner in the Likud and Shas parties, among them being the owner of the newspaper of the then Minister of the Interior's party, rescuing the newspaper from bankruptcy (Drucker 2012).

The social protest of the summer of 2011 (Marom 2013) further enhanced the prominence of distributive justice in the public agenda. However, apart from the legal-bureaucratic and political obstacles, the opposition to revenue redistribution has been based on two major arguments:

- the fear that the additional income channelled to poor municipalities through redistribution would be offset by reduced equalisation grants, if not immediately then at the first instance of an economic or security crisis that would create a need for central-state budget cuts;

- the fear of negatively affecting local autonomy and local initiative in a political system that is anyway excessively centralised; in particular, harming effective 'development agents' in Israel's periphery by diverting resources from effective to less effective municipalities.

\section{A breakthrough in 'top-down' redistribution initiatives}

A breakthrough in the implementation of 'top-down' redistribution mechanisms occurred during the short term of Gideon Saar as Minister of the Interior (2013-2014). It included the first implementation of sections $9 \mathrm{a}$ and $9 \mathrm{~b}$ of the Municipal Order, and the appointment of three 'flagship' commissions to assess a comprehensive revenue redistribution in the Negev (Israel's southern periphery).

A voluntary redistribution agreement between the city of Ofakim and the regional council of Merhavim was endorsed by the Minister according to section $9 \mathrm{a}$, and a redistribution Order between the city of Qiryat Gat and adjacent regional councils was signed by the Minister in January 2014 according to section 9b. The latter included imposed redistribution of property tax revenues paid in the Y.S.Gat industrial park (Fig. 1). It revised the voluntarily agreement first signed in 1995, in favour of the city of Qiryat Gat and added another regional council to the agreement (Lakhish). The imposed redistribution opted to end a decade-long conflict caused by continuous attempts of the city of Qiryat Get to break out of the partnership and keep all revenues within the city.

The three municipal boundary and revenue redistribution commissions appointed in 2013 to assess the redistribution of property taxes of large defence-related and mineral-extracting facilities in the Negev set the precedent in their comprehensive recommendations and in the implementation of those recommendations. The facilities were located in two fiscally sound regional councils (Tamar and Ramat Negev) and in land without municipal jurisdiction (Fig. 1). Under the threat of imposed redistribution, the two regional councils negotiated agreements with some of the adjacent poorer cities and towns. The agreement 
between Ramat Negev and the town of Yeroham included measures of cooperation in local economic development, in addition to revenue redistribution. However, such 'gently imposed' agreements excluded adjacent municipalities from the revenue redistribution (mainly Arab-Bedouin ones), and not necessarily conformed to the law, for example by agreeing to transfer specific sums rather than a proportion of the revenues collected in a particular area.

The three commissions recommended the redistribution of an estimated total of about 73 million shekels (19 million US dollars), of which 25 million shekels to be transferred by the two regional councils and the rest consisting of revenues collected from facilities that were not previously part of any local authority: a large air force base (Nevatim) as well as military industries and electrical facilities in Ramat Beka. Redistribution involved two elements: (1) municipal boundary changes (annexing the facilities located in areas without a municipal jurisdiction to the cities of Beer Sheva and Dimona, and transferring an army base under construction and a defence-related facility from the Ramat Negev regional council to other local authorities), and (2) defining revenue redistribution areas and the share of each of the adjacent local authorities in the tax revenues collected in each area. The recommendations were adopted with minor modifications by the Minister of the Interior - Gideon Saar - as one of his 'flagship' reforms, and implemented just before his resignation, after appeals to the High Court of Justice had failed to postpone action. The credit for the breakthrough could be given to the resolute Minister, but apparently also to the accumulating influence of distributive justice notions in the public agenda since the social protest of 2011, leading to more flexible attitudes of the legal bureaucracy and to a supportive public opinion that makes it more difficult for those opposing redistribution to succeed in political and legal battles.

Redistribution at the regional scale entails a risk of reducing the total amount of public resources available to a region (self-generated revenues of the local authorities and central-state grants and direct expenditures). In the case of the Negev, the regional councils would not be compensated for the loss of revenues transferred to their poorer neighbours because they do not and would not receive central-state equalisation grants. Meanwhile, equalisation grants of the receiving cities and towns would be cut, although not to the full sum gained through revenue redistribution. Hence, the main beneficiary could be the central state's budget. However, the redistribution of revenues from areas previously without municipal jurisdiction should create additional net revenues for the region's local authorities. This latter step required overcoming the opposition of these facilities: the Ministry of Defence, Israel's Military Industries, and the Electrical Company. These challenges were largely met and the remaining challenge (as of March 2015) has been of implementing the imposed redistribution, particularly if sums are not transferred on time as required.

\section{Conclusions}

Although plagued by problems, inter-municipal cooperation in the development of industrial parks, including tax sharing, has evolved and consolidated in Israel for over two decades. These agreements exposed the limitations of voluntary cooperation: a shaky legal basis, susceptibility to disputes (frequently on transferring funds on time, particularly when new mayors are elected), and a weak element of distributive justice. Nevertheless, advantages of voluntary cooperation have also been revealed, particularly in resolving local disputes over annexation, and in joining forces to promote development in peripheral locations.

Joint industrial parks in Israel are an example of a voluntary initiative 'from below', nationalised by the central state for its own objectives: reducing public spending, preserving open space, achieving distributive justice, and political ties and preferences of the Minister. The 'nationalisation' of the initiative from below had contradicting pressure on voluntary cooperation. On the one hand, it hindered initiatives from below, but on the other hand it 'gently imposed' attempts to reach such agreements where redistribution commissions were appointed.

The centralised government structure has overshadowed emerging governance networks in the Israeli case, revealing the vulnerability of an apparent move from hierarchical structures to horizontal governance networks in a centralised 
context. Voluntary cooperation has mainly sought enhanced effectiveness through conflict resolution. However, the mere success of such local collaboration is likely to attract the attention of the central state for both regulating it and utilising the new tool for its own objectives. Promoting aspects of efficiency already requires a measure of 'gentle imposition', and aiming at distributive justice necessitates direct imposition. Indeed, there has appeared some tension between the objectives of distributive justice and reduced public expenditure within the central state. Who will be the main beneficiary of redistribution: the poor local authorities or the central state?

For several years, the passage of a legal framework for revenue redistribution has been an obstacle to rather than a tool for enhancing implementation. It blocked voluntary initiatives while failing to bring imposed redistribution because of hurdles placed by the legal bureaucracy and immense political pressure. One could argue that the central state in Israel is not regarded as a 'fair broker', hence the difficulties in implementation. Nevertheless, nearly eight years after the passage of the legal amendment, a determined minister, apparently assisted by supportive public attitudes towards distributive justice, has managed to achieve a breakthrough in the imposition of revenue redistribution.

Despite the 2014 breakthrough, the Israeli case still suggests one for 'light-touch legislation': legislation that enables, sets some fundamental rules, such as banning the transfer of revenues from residential taxes and levies, and deals with the enforcement of signed agreements. It seems undesirable to opt for detailed laws that attempt to deal with every aspect of imposed redistribution and cooperation. They would only paralyse the mechanisms and not prevent abuse. 'Lighttouch legislation' will make it possible to proceed towards'gently imposed' solutions, in which distribute justice is served in an incremental rather than radical manner, but the risks of undesirable side-effects, such as an erosion of the equalisation grants and excessive centralisation that impairs local development, are also minimised.

\section{References}

Allmendinger P., Haughton G., 2009. Soft spaces, fuzzy boundaries, and metagovernance: The new spatial plan- ning in the Thames Gateway. Environment and Planning A 41: 617-633.

Desage F., Guéranger D., 2013. L'intercommunalité, les maires et notre démocratie. Métropolitiques, 24 avril. Online: http://www.metropolitiques.eu/L-intercommunalite-les-maires-et.html.

Drucker R., 2012. Poverty in Lod thrives, but who benefits from its money? Nana10, 11.12. Online: http://news. nana10.co.il/Article/?ArticleID=937207 (in Hebrew).

Haughton G., Allmendinger P., Oosterlynck S., 2013. Spaces of neoliberal experimentalism: Soft spaces, postpolitics, and neoliberal governmentality. Environment and Planning A 45: 217-234.

Heinelt H., Razin E., Zimmerman K. (eds), 2011. Metropolitan governance, different paths in contrasting contexts: Germany and Israel. Campus, Frankfurt and New York.

Héritier A., Lehmkuhl D., 2008. The shadow of hierarchy and new modes of governance. Journal of Public Policy 28(1): $1-17$.

Hulst R., van Monfort A. (eds), 2007. Inter-municipal cooperation in Europe. Springer, Dordrecht.

Kerrouche E., 2008. L'intercommunalité en France. Montchrestien, Paris.

Marom N., 2013. Activising space: The spatial politics of the 2011 protest movement in Israel. Urban Studies 50(13): 2826-2841.

Nemery J.-C. (ed.), 2010. Quelle nouvelle réforme pour les collectivites territoriales françaises. L'Harmattan, Paris.

Razin E., 1998. Policies to control urban sprawl: Planning regulations or changes in the rules of the game. Urban Studies 35: 321-340.

Razin E., Hazan A., 2001. Redrawing Israel's local government map: Political decisions, court rulings or popular determination. Political Geography 20: 513-533.

Razin E., Hazan A., 2006. Redistributing municipal wealth in Israel. Floersheimer Institute for Policy Studies, Jerusalem (in Hebrew).

Razin E., Hazan A., 2013. Municipal-private partnerships in Israel: From local development to budgetary bypass. In: Pradhan P.K., Bucek J., Razin E. (eds), Geography of governance: Dynamics for local development. International Geographical Union, Commission on Geography of Governance: $77-88$

Ruano de la Fuente J.M., Schaap L., 2007. Democratic legitimacy of inter-municipal and regional governance. In: Bekkers V., Dijkstra G., Edwards A., Fenger M. (eds), Governance and the democratic deficit. Ashgate, Aldershot: 203-222.

Savitch H.V., Vogel R.K., 2000. Paths to new regionalism. State and Local Government Review 32(3): 158-168.

Schaap L., Daemen H. (eds), 2012. Renewal in European local democracies. Springer, Wiesbaden.

Smismans S., 2008. New modes of governance and the participatory myth. West European Politics 31(5): 874-895.

Spicer Z., 2014. Linking regions, linking functions: Inter-municipal agreements in Ontario. Institute on Municipal Finance \& Governance, University of Toronto.

Tennant P., Zirnhelt D., 1973. Metropolitan government in Vancouver: The strategy of gentle imposition. Canadian Public Administration 16(1): 124-138.

Thurmaier K., Wood C., 2004. Interlocal agreement as an alternative to consolidation. In: Carr J.B., Feiock R.C. (eds), City-county consolidation and its alternatives. M.E.Sharpe, Armonk, NY: 113-130.

Wollmann H., 2010. Comparing two logics of interlocal cooperation: The cases of France and Germany. Urban Affairs Review 46(2): 263-292. 